\title{
Hierarchia wartości u osób z zaburzeniami słuchu
}

\section{Value hierarchy of the hard of hearing people}

\section{Anna Cichowska, Zdzisław Marek Kurkowski}

Uniwersytet Marii Curie-Skłodowskiej, Zakład Logopedii i Językoznawstwa Stosowanego, ul. Sowińskiego 17, 20-040 Lublin

Adres autora: Anna Cichowska, Uniwersytet Marii Curie-Skłodowskiej, Zakład Logopedii i Językoznawstwa Stosowanego, ul. Sowińskiego 17, 20-040 Lublin; e-mail: annacichowska@onet.pl

\begin{abstract}
Streszczenie
Wprowadzenie: Niepełnosprawność sensoryczna związana z ubytkiem słuchu w XXI wieku nie jest rzadkim zjawiskiem. Pociąga ona za sobą konsekwencje w każdej sferze funkcjonowania człowieka. Wysunięto hipotezę, że także obszar aksjologiczny będzie się różnił u osób niedosłyszących i ze słuchem w normie. Wartość jest „trwałym przekonaniem, że dany sposób postępowania lub określony stan końcowy jest bardziej pożądany z osobistego lub społecznego punktu widzenia niż postępowanie doń przeciwne”. Same wartości, choć mają wpływ na ludzkie zachowania, są pojęciami abstrakcyjnymi. Te same wartości mogą być cenione przez różnych ludzi, choć w różnym stopniu. Obniżenie zdolności słyszenia, spowodowane różnorodnymi przyczynami, może mieć różną głębokość, a co za tym idzie - konsekwencje, które uwidocznić się mogą także w sferze aksjologicznej.
\end{abstract}

Cel: Przedmiotem badań niniejszej pracy było poszukiwanie odpowiedzi na pytanie czy istnieje różnica w rodzaju preferowanych wartości u osób z różnym poziomem niedosłuchu i osób nie mających problemu ze słuchem i na czym różnice te polegają.

Materiał i metoda: Badania przeprowadzono w Lublinie w 2011 i 2012 roku. Wyodrębniono dwie grupy osób: (1) nie mające problemów ze słuchem i (2) niedosłyszące (wszystkie stopnie niedosłuchu). Badania miały charakter indywidualny i dobrowolny. Do ostatecznych analiz przyjęto 22 badania osób słyszących (przedział wiekowy od 18 do 31 roku życia) i 13 osób z niedosłuchem (od 20 do 27 roku życia). Osoby badane uzupełniały Skalę Wartości (SW) Miltona Rokeacha rangując poszczególne pozycje od 1 do 18. Im niższa ranga, tym bardziej wartość była ceniona przez osobę.

Wyniki: Hipoteza główna zakładająca, że wystąpi istotna statystycznie różnica w hierarchii wartości osób niedosłyszących i słyszących normalnie została potwierdzona, choć w bardzo niewielkim stopniu. Statystycznie istotną różnicę wykryto tylko w odniesieniu do jednej wartości ostatecznej - mądrości. Zauważono jednak pewną tendencję - wśród niektórych wartości były takie, którym do osiągnięcia poziomu istotności statystycznej brakowało kilka setnych.

Wnioski: Należałoby zwiększyć badane grupy i dokonać po raz kolejny analiz statystycznych. Być może udałoby się wówczas wykazać więcej istotnych statystycznie różnic pomiędzy osobami ze słuchem w normie i z niedosłuchem. Zastanowić należy się także, jak można by sprawdzić fakt zrozumienia pozycji zawartych w Skali Wartości, aby wyeliminować możliwość ich niezrozumienia. Na koniec, rozważyć można rozszerzenie badań na osoby z innych miast. Postulat ten wydaje się być zasadny, ponieważ Lublin jest ośrodkiem, gdzie osoby niedosłyszące otoczone są dobrą opieką i wsparciem.

Słowa kluczowe: wartości • osoby z zaburzeniami słuchu

\begin{abstract}
Introduction: In the twenty-first century hearing loss is not uncommon. It has consequences in every sphere of human functioning. Hypothesis was that the axiological area will vary in the hearing impaired and normal hearing people. The value is a permanent conviction that a procedure or a specific final state is more desirable from a personal or social point of view than the proceedings which is opposite it. Although values have an influence on human behavior, they are abstract concepts. These same values can be appreciated by different people, though in varying degrees. Reduction in hearing ability, due to various causes, may have a different depth, and thus - the consequences, which may also show up in the axiological area.
\end{abstract}

Aim: The research of this study was to find answers to the question whether there is a difference in the type of preferred values of the people with hearing loss and those that do not have a problem with hearing and what those differences are. 
Material and methods: The study was put over in Lublin in 2011 and 2012. There were two groups: (1) with no hearing problems, and (2) with hearing loss (all degrees of hearing loss). Studies were individual and voluntary. For the final analysis adopted 22 studies of hearing people (aged from 18 to 31 ) and 13 studies of people with hearing loss (20 to 27 years of age). All of them supplemented Values Scale (SW) by Milton Rokeach by ranking each item from 1 to 18 . The lower the rank, the more value was appreciated by a person.

Results: The main hypothesis assumes that there is a statistically significant difference in the value hierarchy of the hearing impaired and normal hearing people was confirmed (in fact in very small degree). Statistically significant difference was detected only for one value of the final value - wisdom. It was noted, however, a tendency - among some of the values - that to achieve the level of statistical significance was lacking a few hundredths.

Conclusions: To have more reliable results, the study groups should be increased, and once again make a statistical analysis. It might be able to demonstrate the more significant differences between those with normal hearing and hearing loss. We should also consider how to check understanding of the items in the scale of values to eliminate the possibility of misunderstanding. Finally, we can consider the extension of study on people from other cities. This postulate appears to be important because Lublin is a city where people with hearing loss have good care and furtherance.

Key words: values $\bullet$ people with impaired hearing

\section{Wstęp}

W społeczeństwie stykamy się z różnymi ludźmi. Wśród nas są zarówno osoby zdrowe, jak i przejawiające różne deficyty. W ośrodkach uniwersyteckich rozważane jest przystosowanie osób mających problem z odbiorem bodźców akustycznych do środowiska, czy sposoby ich komunikacji. Wydaje się być uzasadnionym spojrzenie na ludzi z uszkodzeniami narządu słuchu także pod kątem aksjologicznym. Po przeanalizowaniu literatury, gdzie często poruszany temat wartości nigdy nie był odniesiony do osób słabosłyszących, postanowiono podjąć próbę zbadania tego tematu.

W poniższej pracy poszukiwana jest odpowiedź na pytanie czy istnieje różnica $\mathrm{w}$ rodzaju preferowanych wartości u osób z różnymi zaburzeniami słuchu i osób nie mających problemu ze słuchem. Sprawdzone zostanie także, czy wartości związane z drugim człowiekiem znajdują się wyżej w hierarchii u osób z niedosłuchem niż u osób poprawnie słyszących. Inne pytanie badawcze to: czy wartości hedonistyczne są bardziej cenione przez osoby słyszące niż przez osoby z niedosłuchem?

Grupą poddaną badaniu skalą wartości była młodzież studiująca na lubelskich uczelniach wyższych z różnymi poziomami niedosłuchu i młodzież słysząca poprawnie.

\section{Wartości - geneza i funkcje}

Konstańczak [2001], próbując dokonać syntezy różnych definicji wartości, stwierdza, że mogą być traktowane jako „drogowskazy dla aktywności ludzkiej”. Tak zdefiniowane postrzegane są jako coś ukazującego drogę, kierujące do zamierzonego celu.

Wartość to coś cennego, pożądanego. Nowa Encyklopedia Powszechna PWN definiuje wartość jako „podstawową kategorię aksjologii, oznaczającą wszystko to, co cenne i godne pożądania, co stanowi cel dążeń ludzkich” [za: red. Petrozelin-Skowrońska, 1997]. Przyjęte wartości stanowią fundament ocen, norm i wzorów kulturowych.

Wartości z perspektywy poznawczo-przeżyciowej teorii „ja” opisuje Epstein [1990, s. 12]. W swoim artykule twierdzi, że są one „przekonaniami o tym, co pożądane, organizującymi doświadczenie i sterującymi zachowaniem w odniesieniu do pewnych szerokich klas zdarzeń”. To, co ma dla człowieka znaczenie, jest dla niego wartością. Widzi on wartości jako coś, na co zwracamy naszą uwagę, czego poszukujemy i co ukierunkowuje nasze działanie i zapamiętywanie. Ujawniają się one w emocjach, myśleniu, a przede wszystkim w zachowaniu w sytuacji wolnego wyboru.

Rokeach [1973, s. 5], jeden z największych badaczy wartości, twierdzi, że „wartość jest trwałym przekonaniem, że dany sposób postępowania lub określony stan końcowy jest bardziej pożądany $\mathrm{z}$ osobistego lub społecznego punktu widzenia niż postępowanie doń przeciwne”. Podkreślone jest tu stanowisko osoby dotyczące jej zachowania i ewentualnych jego konsekwencji. Preferuje ona jedne rzeczy, środki do ich pozyskania lub dany rodzaj postępowania, jednocześnie inne - przeciwne - bez wahania odrzucając. Wartości mają więc wpływ na ludzkie zachowania. Sama wartość jest pojęciem abstrakcyjnym, wyznaczającym preferencje celom i środkom do ich uzyskania.

Rokeach stworzył teorię wartości, będącą częścią teorii osobowości, która jest systemem przekonań, w którym wyodrębnić można 10 głównych podsystemów. Zajmują one różne miejsce w strukturze przekonań - od najbardziej centralnych do najbardziej peryferycznych: (1) przekonania na temat własnego „ja”; (2) system wartości ostatecznych, w skład którego wchodzą wartości indywidualne i społeczne; (3) system wartości instrumentalnych, na który składają się wartości moralne i kompetencyjne; (4) systemy postaw (...); (5) pojedyncze postawy; (6) przekonania o własnych zachowaniach; (7) przekonania o postawach osób znaczących; (8) przekonania o wartościach i potrzebach osób znaczących; (9) przekonania o zachowaniach osób znaczących; (10) przekonania o zachowaniu się obiektów niespołecznych [za: Brzozowski, 1989, s. 3-4].

O tym, jak ważne są dla człowieka wartości i jak doniosłą funkcję regulacyjną spełniają, świadczy ich wyodrębnienie i centralne położenie w systemie przekonań. Centralność wpływa na to, że są one mało podatne na zmiany. „System wartości jest trwałą organizacją przekonań o preferowanych sposobach postępowania lub ostatecznych stanach 
egzystencji, uporządkowanych według względnej ważności” [Rokeach, 1973 za: Brzozowski, 1989, s. 4]. Dzięki temu człowiek może cenić bardziej jakąś wartość, inną zaś uważać za mało ważną. Zmiana kolejności wartości w hierarchii pociągnąć może za sobą zmiany w całym systemie poznawczym, postawach i zachowaniach człowieka. Tym, co inicjować możne modyfikacje w systemie przekonań jest „dążenie do utrzymania i polepszenia wyobrażeń o samym sobie (poczucie własnej wartości)" [za: Brzozowski, 1989, s. 5]. Rokeach uważa również, że wszyscy ludzie cenią te same wartości, choć w różnym stopniu. Wartości zaś dzieli na ostateczne - najważniejsze, ponadsytuacyjne cele w życiu oraz instrumentalne - dotyczące ogólnych sposobów postępowania i przydatne w realizacji ostatecznych. Ich zestawienie ukazuje Tabela 1.

Jedną z cech wartości jest możliwość poddania ich systematyzacji pod względem różnych aspektów. Nabywamy je w różnych okolicznościach, wzorując się na innych ludziach i układamy według naszych preferencji. Najczęściej hierarchizuje się je pod względem ważności, od najważniejszych do najmniej cenionych przez konkretną osobę. W różnych środowiskach preferowane mogą być inne wartości, a od wpływu tych środowisk zależeć może, jak jednostka je zhierarchizuje.

Na wybór moralnego rozumowania i odpowiednich wartości wpływ mają różnorodne czynniki. To jednak w środowisku domowym, które jest pierwszym i najbliższym rozwijającemu się dziecku miejscem, kształtują się wartości od początku życia. „Rodzina jest najwłaściwszym środowiskiem, w którym dziecko może żyć i rozwijać się uzyskując dostęp do wszystkich wartości stworzonych dla ludzi i przez ludzi" [Krakowiak, 2003, s. 15]. Podobnie Stocklin-Meier [2006] pisze, że to przede wszystkim od domu rodzinnego oczekuje się ukazywania i nauczania dziecka wartości. W literaturze spotyka się także twierdzenie, że te wartości, które charakterystyczne są dla danej kultury, przekazywane sa $\mathrm{z}$ pokolenia na pokolenie [Birch \& Malim, 2002]. W naszym pierwszym środowisku - rodzinie - poprzez obserwację przyswajamy jako dzieci to, co preferowane jest przez rodziców. Czasem werbalizują oni wyznawane wartości nauczając o nich, czasem jednak dzieci nieświadomie je przejmują. Własna hierarchia, którą tworzy każde dziecko, nie jest prostą kopią usystematyzowanych wartości rodziców. Maslow (1990) co prawda zauważył, że są one częściowo zdeterminowane biologicznie [za: Sawczuk, 2000], jednak nie można na nie patrzeć tylko jednostronnie. Loehlin (1997) wysunął tzw. „hipotezę barową”. Obrazuje ona wybieranie przez człowieka wartości. Zgodnie z nią każda osoba co prawda przyswaja proponowane przez kulturę, w której się wychowuje wartości, jednak to, co wybierze zależy nie tylko od ofert „przy ladzie barowej”, ale również od jej własnych preferencji [za: Brzozowski, 2007]. Rodzice mogą więc pokazywać dziecku to, co jest dla nich ważne, lecz ono samo ma możliwość ich wyboru lub odrzucenia.

Wśród czynników, od których zależy rozumowanie prospołeczne i wartości zgodnie z nim wybierane, wymienia się techniki wychowawcze rodziców, modelowanie, obserwację oddziaływania norm i wartości na socjalizatorów i kulturę [Eisenberg, 1990].

Żyjąc w społeczeństwie i będąc jego nieodłącznym elementem, nawiązujemy bardzo dużo relacji z innymi ludźmi. To
Tabela 1. Wartości ostateczne i instrumentalne wyróżnione przez Rokeacha (Opracowanie własne na podstawie Brzozowski, 1989)

\begin{tabular}{|c|c|}
\hline Wartości ostateczne & Wartości instrumentalne \\
\hline Bezpieczeństwo narodowe & Ambitny \\
\hline Bezpieczeństwo rodziny & Czysty \\
\hline Dojrzała miłość & Intelektualista \\
\hline Dostatnie życie & Kochający \\
\hline Mądrość & Logiczny \\
\hline Poczucie dokonania & Niezależny \\
\hline Poczucie własnej godności & O szerokich horyzontach \\
\hline Pokój na świecie & Obdarzony wyobraźnią \\
\hline Prawdziwa przyjaźń & Odpowiedzialny \\
\hline Przyjemność & Odważny \\
\hline Równowaga wewnętrzna & Opanowany \\
\hline Równość & Pogodny \\
\hline Szczęście & Pomocny \\
\hline Świat piękna & Posłuszny \\
\hline Uznanie społeczne & Uczciwy \\
\hline Wolność & Uprzejmy \\
\hline Zbawienie & Uzdolniony \\
\hline Życie pełne wrażeń & Wybaczający \\
\hline
\end{tabular}

właśnie one umożliwiają poznanie nowych wartości i popychają do ciągłego rozwoju. Dziecko mające kontakt z osobami w tym samym lub podobnym wieku, ma szansę poznać odmienny sposób widzenia i oceny świata. Czasem różnice te sa niewielkie, czasem zaś wartości przejawiane przez rówieśników znacząco różnią się od tych wyniesionych z domu. Wystąpić może wówczas konflikt, którego rozwiązanie rzutować będzie na postępowanie młodego człowieka.

$\mathrm{Z}$ jednej strony wartość to byt abstrakcyjny, teoretyczny, $\mathrm{z}$ drugiej natomiast realnie wpływa na nasze postępowanie. „W zakresie postaw i zachowania stwarzają one predyspozycje o charakterze regulująco-kierunkującym, inicjującym i dynamizującym działanie, oraz o charakterze motywacyjnym, selektywnym, predyktywnym" [Sękowski, 1994, za: Kalicka, 2007, s. 24]. W literaturze przedmiotu często spotykany jest pogląd o regulacyjnej funkcji wartości: „podobnie jak normy są związane z poglądem na świat i w ramach struktury osobowości pełnią istotne funkcje regulacyjne. Po pierwsze regulują zaspokajanie potrzeb, określając które potrzeby i w jakiej kolejności mają być zaspokojone, szczególnie w sytuacjach i warunkach, kiedy zaspokojenie wszystkich potrzeb nie jest możliwe. Po drugie wpływają na wybór celów, zwłaszcza odległych oraz sposobów ich realizacji. Preferowane przez osobę wartości stanowią także źródło ocen siebie samego, innych osób, grup społecznych, instytucji” [Mądrzycki, 1996, za: Martynowicz, 2004, s. 53]. Warto jednak zaznaczyć, iż 
regulacyjna rola wartości występuje jedynie u osób, których system wartości osobistych jest dobrze wykształconą, zorganizowaną strukturą umysłową, rzeczywistą hierarchią preferencyjną [Wojciszke, 1990]. Taki człowiek kroczy wykreowaną przez siebie indywidualną ścieżką życia. Źródeł wskazówek zachowania doszukiwać się można w pozycji, jaką zajmują poszczególne wartości w hierarchii. Im coś jest bardziej preferowane, im jest wyżej cenione, tym bardziej prawdopodobne, że właśnie ta wartość wpłynie na zachowanie. Jak zauważa Czerniawska [2002], zachowania warunkowane są przez wyższe preferencje o różnym charakterze: intrapersonalnym, interpersonalnym, hedonistycznym lub sprawnościowym.

Rokeach [1973 za: Czerniawska, 1995, s. 27] pisał, że imperatywem działania są wartości, gdyż to one oddziałują na postawy. Wartości pociągają człowieka do zrobienia czegoś, dlatego też wiąże się z nimi wiele innych psychologicznych pojęć, jak pragnienia, potrzeby, motywacja. Oddziałują one na trzy wymiary postawy: behawioralny (zachowania), emocjonalny (emocjonalna ocena wynikająca z preferowanych wartości) i poznawczy (wyznaczanie aspektów spostrzegania różnych zjawisk i przedmiotów) [Sękowski, 1994, za: Kalicka, 2007]. Postawa jednak jest pojęciem szerszym od pojęcia wartości i nie ma aspektu pragnienia.

Wartości mogą być także źródłem motywacji [Staub, 1990]. To, jak człowiek ocenia pewne dobra i zachowania może motywować go do takiego działania, aby nie powstało zjawisko dysonansu. Stara się on postępować zgodnie z wyznawanymi wartościami.

\section{Hierarchia wartości u osób niedosłyszących}

„Uznaje się, że społeczność złożona z osób niesłyszących wytwarza samowystarczalną kulturę, opartą na własnym językowym obrazie świata i na własnym systemie wartości" [Krakowiak, 2003, s. 9]. Dlatego też wysunięta została hipoteza o różnicach pomiędzy pereferowanymi wartościami osób słyszących normalnie i niedosłyszących.

Dla rodziców ważne jest, aby ich niedosłyszące dziecko poradziło sobie w życiu. Posyłają je więc niejednokrotnie na zajęcia pozaszkolne - surdopedagogiczne, logopedyczne i inne chcąc usprawnić jego funkcjonowanie. W efekcie od najmłodszych lat większy nacisk położony może być na rewalidację i rehabilitację słuchu i mowy niż na funkcjonowanie emocjonalno-społeczne. Może powodować to niepełne zaspokojenie potrzeb związanych $\mathrm{z}$ afiliacją, przynależnością do grupy i innych. Dla rodziców, nie znających sytuacji społecznej swojego dziecka w grupie rówieśniczej, bardziej liczy się, że jest ono w klasie, gdzie rozwijać może język. „Większość rodziców nie werbalizuje oczekiwań wobec szkoły, związanych z integracją społeczną ich dzieci w klasie integracyjnej" [Kobosko i wsp., 2004, s. 143]. Także szkoła często nie zapewnia warunków mogących wspierać społeczną integrację dzieci z wadą słuchu i słyszących, nie wprowadza treningów umiejętności interpersonalnych czy programów kompetencji społecznych, które mogłyby bardzo pomóc niepełnosprawnym.

Sprawnie migające osoby niedosłyszące i niesłyszące bez kłopotu porozumiewają się w swojej społeczności oraz nie odczuwają przykrości związanych z kontaktem z osobą słyszącą, gdzie próbują one komunikować się werbalnie, co jest źródłem wadliwej artykulacji, błędów językowych a co za tym idzie - poczucia niższości, napięcia i lęku [Krakowiak, 2003]. Taki kontakt jest jednak możliwy jedynie w ograniczonej grupie osób. Pewne potrzeby mogą być jednak niezaspokojone, np. te związane z kontaktem z osobami normalnie słyszącymi. Czy w związku z tym niedosłyszący będą wyżej cenili wartości międzyludzkie?

Abraham Maslow, najbardziej znany przedstawiciel psychologii humanistycznej, opracował teorię potrzeb dzieląc je na dwie główne grupy: potrzeby podstawowe (fizjologiczne, niedoboru) i metapotrzeby (wzrostu). Do pierwszej grupy zaliczył np.: potrzebę głodu, pragnienia, wydalania, snu, seksu itp. które każdy człowiek musi zaspokoić, aby przetrwać. Do drugiej z kolei zaliczył te, które obejmują potrzebę bezpieczeństwa, sprawiedliwości, dobra, piękna, porządku, miłości, przynależności, szacunku, samourzeczywistniania się i inne. Różnią się one od poprzednich tym, że aby je zaspokoić, nie trzeba odczuwać stanu braku i że mogą być wyuczane [Rathus, 2004]. Niezaspokojenie każdego rodzaju potrzeb powodować może chorobę fizyczną lub problemy natury psychicznej. Do metachorobowych stanów należą zdaniem autora teorii cynizm, apatia, alienacja [Hall i wsp., 2006]. Źródeł frustracji w niezaspokojeniu potrzeb doszukiwał się Maslow najczęściej na poziomie potrzeb społecznych: przynależności i miłości [Rathus, 2004]. Ich zaspokojenie jest jeszcze trudniejsze dla osób z niedosłuchem, gdyż mają one ograniczone grono rozumiejących ich osób. Sposoby zaspokajania potrzeb zależne są od możliwości organizmu i zasad przyjętych przez środowisko społeczno-kulturowe [Pervin \& John, 2002]. Osoba niedosłysząca, mająca problem $\mathrm{z}$ werbalnym porozumiewaniem się z ogółem społeczeństwa, może odczuwać nieprzyjemne konsekwencje stanu deprywacji potrzeby afiliacji, przynależności, szacunku czy władzy. Niezaspokojenie takich potrzeb może powodować ich większe docenianie i silniejsze dążenie do ich nasycenia.

\section{Strategia badań własnych}

Badania mają na celu znalezienie odpowiedzi na pytanie czy istnieje różnica $\mathrm{w}$ wartościach preferowanych przez osoby niedosłyszące i słyszące poprawnie. Przyjmując podział wartości za Miltonem Rokeachem zostanie sprawdzone jakie wartości ostateczne i instrumentalne są preferowane przez każdą z grup oraz czy istnieją między nimi różnice istotne statystycznie.

Jeżeli hipoteza o istnieniu różnic w systemach wartości się potwierdzi, sprawdzone zostanie, czy wartości związane $\mathrm{z}$ drugim człowiekiem znajdują się wyżej w hierarchii u osób z niedosłuchem niż u osób poprawnie słyszących oraz czy wartości hedonistyczne są bardziej cenione przez osoby słyszące niż przez osoby z uszkodzeniem słuchu.

Metodą stosowaną w badaniach jest Skala Preferencji Wartości (SW) osadzona na teorii wartości Rokeacha, który podzielił je na ostateczne (WO) i instrumentalne (WI) (por. Tabela 1). Test jest adaptacją amerykańskiej wersji Value Survey (VS). Metoda składa się z dwu równolicznych podskal poprzedzonych instrukcją. Wykorzystana 
Tabela 2. Hierarchia wartości ostatecznych osób słyszących normalnie

\begin{tabular}{cccccc}
\hline Lp. w skali & Wartości ostateczne & Me & Min & Max & Rozstęp ćwiartkowy \\
\hline WO_13 & Szczęście & 3 & 1 & 11 & 4 \\
\hline WO_3 & Dojrzała miłość & 3,5 & 1 & 17 & 6,50 \\
\hline WO_2 & Bezpieczeństwo rodziny & 4 & 1 & 13 & 5,50 \\
\hline WO_16 & Wolność & 6 & 1 & 13 & 6,50 \\
\hline WO_5 & Mądrość & 7 & 1 & 14 & 7,50 \\
\hline WO_7 & Poczucie własnej godności & 7 & 1 & 14 & 8,25 \\
\hline WO_9 & Prawdziwa przyjaźń & 8 & 2 & 16 & 6,25 \\
\hline WO_11 & Równowaga wewnętrzna & 8,5 & 2 & 17 & 9,25 \\
\hline WO_15 & Uznanie społeczne & 10,5 & 4 & 18 & 5,25 \\
\hline WO_4 & Dostatnie życie & 11 & 2 & 17 & 4,75 \\
\hline WO_6 & Poczucie dokonania & 11 & 5 & 17 & 3,25 \\
\hline WO_10 & Przyjemność & 11 & 1 & 18 & 8,25 \\
\hline WO_18 & Życie pełne wrażeń & 11 & 1 & 18 & 9 \\
\hline WO_12 & Równość & 14 & 3 & 18 & 4,25 \\
\hline WO_8 & Pokój na świecie & 14,5 & 2 & 18 & 7,25 \\
\hline WO_17 & Zbawienie & 14,5 & 1 & 18 & 12,25 \\
\hline WO_1 & Bezpieczeństwo narodowe & 15 & 3 & 18 & 8,25 \\
\hline WO_14 & Świat piękna & 15 & 3 & 18 & 4,25 \\
\hline
\end{tabular}

została wersja E-4 Skali Preferencji Wartości, która jest najpowszechniej stosowaną wersją. Zawiera ona przy pozycjach wartości zwroty je definiujące. Wartości (po 18 w podskali) uporządkowane są alfabetycznie [Brzozowski, 1989]. Stabilność podskal jest wysoka.

Zadaniem osób badanych było porangowanie w wyznaczonym miejscu po lewej stronie pozycji. Rangę pierwszą otrzymywała ta wartość, która jest dla osoby badanej najważniejsza, rangę drugą ta, która zajmuje drugie miejsce pod względem ważności, itd. Ta wartość, która jest najmniej ważna otrzymywała liczbę 18 . Nie można było wpisać tej samej liczby obok dwu różnych wartości.

Efektem badania Skalą Preferencji Wartości Rokeacha było uzyskanie danych obrazujących systemy wartości każdej badanej osoby.

Badania przeprowadzono w Lublinie w 2011 i 2012 roku. Założono, że przebadane zostaną dwie grupy osób: (1) nie mające problemów ze słuchem i (2) niedosłyszące (wszystkie stopnie niedosłuchu). Noszenie aparatu słuchowego nie wykluczało udziału w badaniach (osoby zaznaczały ten fakt w odpowiednim miejscu w wypełnianej ankiecie). Zostali oni ogólnie poinformowani o celu badania i stosowanej metodzie. Słabosłyszący mieli prawo poprosić o wyjaśnienie w razie niezrozumienia instrukcji, z czego część skorzystała. Osobom słyszącym nie były udzielane żadne dodatkowe podpowiedzi. Badania miały charakter indywidualny i dobrowolny, odbywały się po wcześniejszym ustaleniu czasu i miejsca spotkania. Wypełnienie ankiety zajmowało respondentom od 20 do 40 minut, choć czas nie był ograniczony.
Przebadano łącznie 60 osób: 30 niemających problemów ze słuchem i 30 niedosłyszących. Stosowana skala okazała się zbyt skomplikowana dla części badanych. Wśród wypełnionych ankiet do dalszych analiz przyjęto jedynie 22 badania osób słyszących i 13 osób z niedosłuchem, których wyniki można było uznać za rzetelne. Odrzucono arkusze, z których wynikało, że osoba całkowicie nie zrozumiała polecenia, w których występowały braki danych, powtórzone lub ominięte rangi oraz takie, których wygląd wskazywał na losowe odpowiadanie na pytania.

Osoby, które wypełniły poprawnie ankiety to studenci lubelskich uczelni wyższych wszystkich lat studiów. Przedział wiekowy słyszących obejmował osoby od 18 do 31 roku życia, zaś niedosłyszących od 20 do 27 roku życia. Średnia i odchylenie w obu grupach były zbliżone. Wśród osób badanych większość stanowiły kobiety, co mogło wpłynąć na otrzymane wyniki. Dobrowolność wypełniania ankiet i to, że duża część została odrzucona także wpłynęło na proporcje liczebności respondentów.

Wśród zbadanych osób z problemami ze słuchem, nie pojawili się respondenci z lekkim niedosłuchem. 54\% stanowili badani $\mathrm{z}$ niedosłuchem umiarkowanym, $8 \%$ znacznym, a 38\% głębokim. Wśród tych 4 grup niedosłuch odbiorczy zdiagnozowany został u $38 \%$, a przewodzeniowy u $23 \%$. Kolejne $38 \%$ nie potrafiło określić rodzaju swojego niedosłuchu. W badanej grupie niedosłyszących tylko jedna osoba (niedosłuch przewodzeniowy, umiarkowany) nie miała założonego aparatu słuchowego.

Tylko jedna osoba $\mathrm{z}$ badanej grupy nie posługuje się językiem mówionym. Pozostałe niedosłyszące osoby badane 
Tabela 3. Hierarchia wartości ostatecznych osób mających problemy ze słuchem

\begin{tabular}{cccccc}
\hline Lp. w skali & Wartości ostateczne & Me & Min & Max & Rozstęp ćwiartkowy \\
\hline WO_2 & Bezpieczeństwo rodziny & 4 & 1 & 12 & 5,50 \\
\hline WO_3 & Dojrzała miłość & 4 & 1 & 8 & 4,50 \\
\hline WO_5 & Mądrość & 4 & 1 & 9 & 4,50 \\
\hline WO_11 & Równowaga wewnętrzna & 6 & 1 & 15 & 6 \\
\hline WO_7 & Poczucie własnej godności & 7 & 1 & 17 & 7,50 \\
\hline WO_9 & Prawdziwa przyjaźń & 7 & 2 & 18 & 5,50 \\
\hline WO_13 & Szczęście & 7 & 1 & 15 & 7 \\
\hline WO_4 & Dostatnie życie & 9 & 2 & 17 & 5,50 \\
\hline WO_6 & Poczucie dokonania & 10 & 3 & 16 & 6 \\
\hline WO_16 & Wolność & 10 & 1 & 12 & 6,50 \\
\hline WO_8 & Pokój na świecie & 12 & 4 & 18 & 8 \\
\hline WO_12 & Równość & 12 & 8 & 18 & 5 \\
\hline WO_10 & Przyjemność & 13 & 4 & 18 & 7,50 \\
\hline WO_17 & Zbawienie & 13 & 1 & 17 & 12 \\
\hline WO_1 & Bezpieczeństwo narodowe & 14 & 3 & 18 & 9,50 \\
\hline WO_15 & Uznanie społeczne & 15 & 4 & 18 & 6,50 \\
\hline WO_18 & Życie pełne wrażeń & 15 & 5 & 18 & 5 \\
\hline WO_14 & Świat piękna & 16 & 4 & 18 & 6,50 \\
\hline
\end{tabular}

zaznaczały, które określenie odnośnie języka mówionego jest najbardziej charakterystyczne dla nich. Ponad połowa osób nie ma problemów z językiem mówionym i się nim posługuje.

\section{Prezentacja wyników badań}

Respondentów podzielono na dwie grupy osób: słyszących prawidłowo, którą nazwano kontrolną (22 respondentów) i z niedosłuchem różnego rodzaju i stopnia (grupa eksperymentalna) (13 respondentów). Prezentowane wyniki i ich analiza posłużyły do weryfikacji postawionych hipotez badawczych. Zebrane dane poddano wnikliwej analizie statystycznej i podjęto próbę ich wyjaśnienia.

Preferencja wartości ostatecznych w badanych grupach

Wartości ostateczne (Tabela 2), które okazały się być najważniejsze dla grupy osób słyszących to: szczęście $(\mathrm{Me}=3)$, dojrzała miłość $(\mathrm{Me}=3,5)$ i bezpieczeństwo rodziny $(\mathrm{Me}=4)$. Połowa tej grupy przypisała tym trzem wartościom rangę co najmniej czwartą. Rozstęp ćwiartkowy, będący różnicą pomiędzy trzecim i pierwszym kwartylem, ukazuje zróżnicowanie wyników, ponieważ pomiędzy tymi kwartylami znajduje się 50\% danych. Zauważyć można, że osoby badane były najbardziej zgodne w preferencji wartości ostatecznej będącej na pierwszym miejscu - szczęścia. Najmniej cenione wartości ostateczne w grupie osób niemających problemów ze słuchem to: świat piękna $(\mathrm{Me}=15)$, bezpieczeństwo narodowe $(\mathrm{Me}=15)$, zbawienie $(\mathrm{Me}=14,5)$, pokój na świecie $(\mathrm{Me}=14,5)$ i równość $(\mathrm{Me}=14)$. Wartości te postawione zostały przez $50 \%$ badanych najwyżej na czternastej lub piętnastej pozycji spośród osiemnastu możliwych. Rangi przypisywane wartości zbawienie były najbardziej zróżnicowane w tej grupie.
Najbardziej preferowanymi wśród osób z niedosłuchem (Tabela 3) wartościami ostatecznymi okazały się: bezpieczeństwo rodziny $(\mathrm{Me}=4)$, dojrzała miłość $(\mathrm{Me}=4)$ i mądrość $(\mathrm{Me}=4)$. Połowa respondentów z tej grupy stawiała te wartości co najmniej na czwartym miejscu. Rozstęp ćwiartkowy tych wartości pokazuje, że najmniejsze zróżnicowanie przypisywanych rang występuje w odniesieniu do pozycji dojrzała miłość i mądrość. Najmniej cenionymi okazały się zaś: świat piękna $(\mathrm{Me}=16)$, życie pełne wrażeń $(\mathrm{Me}=15)$, uznanie społeczne $(\mathrm{Me}=15)$ i bezpieczeństwo narodowe $(\mathrm{Me}=14)$. Połowa badanych umieszczała je dopiero na czternastej, piętnastej lub szesnastej pozycji na osiemnaście możliwych.

$\mathrm{Z}$ rang przypisanych każdej wartości obliczono medianę. Aby zobrazować różnice otrzymanych median uzyskanych dla każdej wartości w obu badanych grupach, sporządzono wykres (por. Rycina 1), gdzie:

WO - wartości ostateczne,

Me_Słuch - mediana danej wartości w grupie osób słyszących normalnie,

Me_Niedosłuch - mediana danej wartości w grupie osób $\mathrm{z}$ niedosłuchem,

WO_1 - Bezpieczeństwo narodowe;

WO_2 - Bezpieczeństwo rodziny,

WO_3 - Dojrzała miłość,

WO_4 - Dostatnie życie,

WO_5 - Mądrość,

WO_6 - Poczucie dokonania,

WO_7 - Poczucie własnej godności,

WO_8 - Pokój na świecie,

WO_9 - Prawdziwa przyjaźń,

WO_10 - Przyjemność,

WO_11 - Równowaga wewnętrzna,

WO_12 - Równość, 


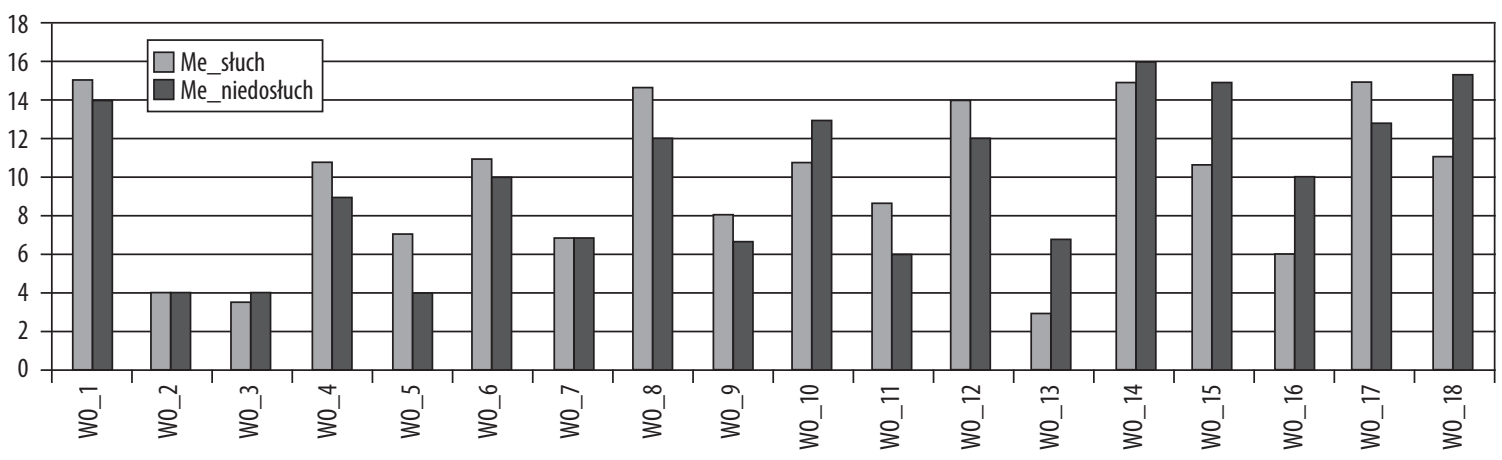

Rycina 1. Mediany wartości ostatecznych w obu grupach badanych

WO_13 - Szczęście,

WO_14 - Świat piękna,

WO_15 - Uznanie społeczne,

WO_16 - Wolność,

WO_17 - Zbawienie,

WO_18 - Życie pełne wrażeń.

Preferencja wartości instrumentalnych w badanych grupach

Na podstawie wyników można stwierdzić, że w grupie osób słyszących (Tabela 4) najbardziej preferowane wartości instrumentalne to: odpowiedzialny $(\mathrm{Me}=3,5)$, niezależny $(\mathrm{Me}=5)$ i uczciwy $(\mathrm{Me}=5)$. Przez 50\% grupy wartości te były najniżej na 3, 4 lub 5 pozycji. Wśród nich najmniejsze zróżnicowanie przypisywanych rang występuje w odniesieniu do pozycji odpowiedzialny. Najmniej cenione okazały się wartości: posłuszny $(\mathrm{Me}=17)$ i wybaczający $(\mathrm{Me}=15,5)$. Były one umieszczone najwyżej na 15, $16 \mathrm{lub}$ 17 pozycji przez połowę grupy. Osoby słyszące były najbardziej zgodne w preferencji wartości instrumentalnej będącej na pierwszym miejscu zestawienia - wartości posłuszny.

Wyniki uzyskane w grupie osób z uszkodzonym narządem słuchu (Tabela 5) wskazują na preferencję wartości ambitny $(\mathrm{Me}=4)$, kochający $(\mathrm{Me}=5)$ i odpowiedzialny $(\mathrm{Me}=5)$. Połowa tej grupy przypisała tym trzem wartościom rangę co najmniej czwartą lub piątą. Rozstęp ćwiartkowy wskazuje na duże zróżnicowanie wyników, które zostały wzięte do obliczenia median $\mathrm{z}$ tych rang. Najmniej cenioną wartością instrumentalną w tej grupie okazała się być pozycja obdarzony wyobraźnią $(\mathrm{Me}=15)$. Została ona postawiona przez 50\% badanych najwyżej na piętnastej pozycji spośród osiemnastu możliwych.

Tabela 4. Hierarchia wartości instrumentalnych osób ze słuchem w normie

\begin{tabular}{cccccc}
\hline Lp. w skali & Wartości instrumentalne & Me & Min & Max & Rozstęp ćwiartkowy \\
\hline WI_8 & Odpowiedzialny & 3,5 & 1 & 15 & 4,50 \\
\hline WI_6 & Niezależny & 5 & 1 & 18 & 9 \\
\hline WI_15 & Uczciwy & 5 & 1 & 16 & 4,75 \\
\hline WI_3 & Intelektualista & 7,5 & 1 & 17 & 10,50 \\
\hline WI_1 & Ambitny & 8 & 1 & 18 & 10,50 \\
\hline WI_4 & Kochający & 8 & 1 & 15 & 10 \\
\hline WI_5 & Logiczny & 8 & 1 & 18 & 9,75 \\
\hline WI_13 & Pomocny & 8 & 1 & 16 & 6 \\
\hline WI_9 & Odważny & 9,5 & 2 & 16 & 4,25 \\
\hline WI_10 & Opanowany & 9,5 & 1 & 18 & 8,75 \\
\hline WI_16 & Uprzejmy & 10 & 5 & 17 & 5 \\
\hline WI_11 & Pogodny & 10,5 & 1 & 17 & 8,25 \\
\hline WI_7 & Obdarzony wyobraźnią & 11,5 & 4 & 18 & 7,25 \\
\hline WI_2 & Czysty & 12 & 1 & 17 & 11,25 \\
\hline WI_12 & O szerokich horyzontach & 12 & 3 & 18 & 6,25 \\
\hline WI_17 & Uzdolniony & 12,5 & 2 & 18 & 9,25 \\
\hline WI_18 & Wybaczający & 15,5 & 2 & 18 & 9,25 \\
\hline WI_14 & Posłuszny & 17 & 11 & 18 & 4,25 \\
\hline
\end{tabular}


Tabela 5. Hierarchia wartości instrumentalnych osób niedosłyszących

\begin{tabular}{cccccc}
\hline Lp. w skali & Wartości instrumentalne & Me & Min & Max & Rozstęp ćwiartkowy \\
\hline WI_1 & Ambitny & 4 & 1 & 17 & 8 \\
\hline WI_4 & Kochający & 5 & 1 & 18 & 9 \\
\hline WI_8 & Odpowiedzialny & 5 & 1 & 13 & 7 \\
\hline WI_2 & Czysty & 6 & 2 & 15 & 6 \\
\hline WI_3 & Intelektualista & 6 & 2 & 18 & 5 \\
\hline WI_13 & Pomocny & 8 & 2 & 13 & 6 \\
\hline WI_15 & Uczciwy & 8 & 1 & 16 & 10,50 \\
\hline WI_9 & Odważny & 9 & 1 & 17 & 8 \\
\hline WI_5 & Logiczny & 10 & 2 & 15 & 10 \\
\hline WI_6 & Niezależny & 10 & 1 & 17 & 5 \\
\hline WI_18 & Wybaczający & 10 & 3 & 18 & 9 \\
\hline WI_17 & Uzdolniony & 11 & 1 & 18 & 10,50 \\
\hline WI_10 & Opanowany & 12 & 4 & 18 & 7 \\
\hline WI_11 & Pogodny & 12 & 3 & 18 & 8 \\
\hline WI_12 & O szerokich horyzontach & 13 & 1 & 18 & 7,50 \\
\hline WI_14 & Posłuszny & 13 & 8 & 18 & 4 \\
\hline WI_16 & Uprzejmy & 13 & 2 & 17 & 7,50 \\
\hline WI_7 & Obdarzony wyobraźnią & 15 & 1 & 18 & 10 \\
\hline
\end{tabular}

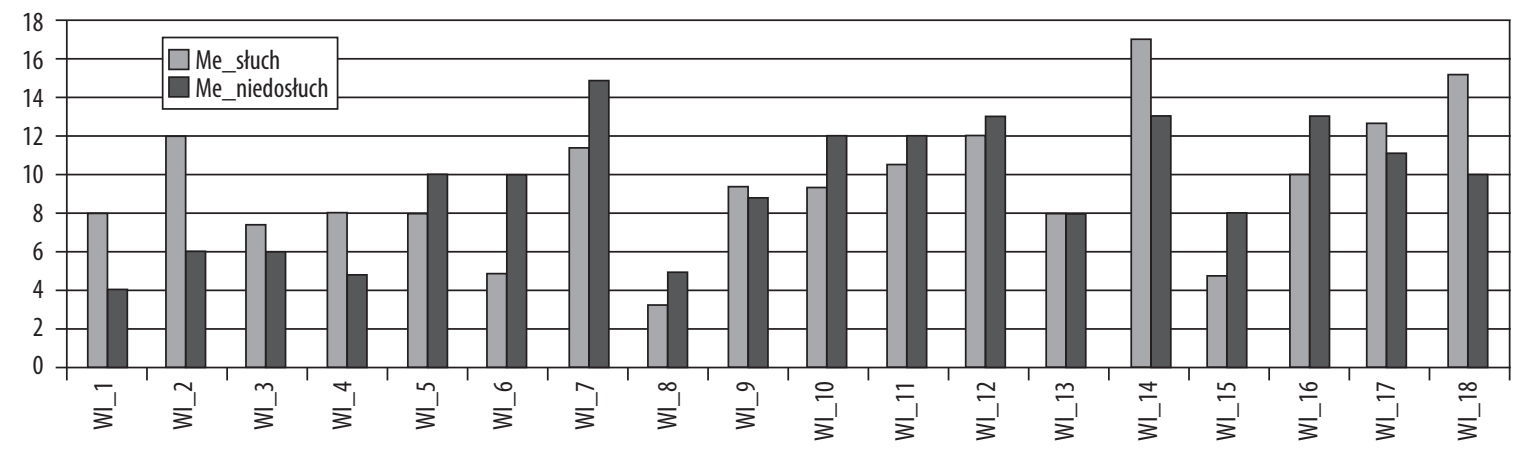

Rycina 2. Mediany wartości instrumentalnych w obu grupach badanych

W celu ukazania różnic uzyskanych median dla każdej wartości instrumentalnej w obu grupach sporządzono wykres (Rycina 2), gdzie:

WI - wartości instrumentalne,

Me_Słuch - mediana danej wartości w grupie osób słyszących normalnie,

Me_Niedosłuch - mediana danej wartości w grupie osób z niedosłuchem,

WI_1 - Ambitny,

WI_2 - Czysty,

WI_3 - Intelektualista,

WI_4 - Kochający,

WI_5 - Logiczny,

WI_6 - Niezależny,

WI_7 - Obdarzony wyobraźnią,

WI_8 - Odpowiedzialny,

WI_9 - Odważny,
WI_10 - Opanowany,

WI_11 - Pogodny,

WI_12 - O szerokich horyzontach,

WI_13 - Pomocny,

WI_14 - Posłuszny,

WI_15 - Uczciwy,

WI_16 - Uprzejmy,

WI_17 - Uzdolniony,

WI_18 - Wybaczający.

Różnice w preferowanych wartościach w badanych grupach

Celem pracy jest sprawdzenie, czy istnieją różnice w preferencji wartości osób słyszących normalnie i z niedosłuchem. Aby tego dokonać zebrane dane poddano analizie stosując test U Manna-Whitneya (test dla danych 
Tabela 6. Różnice w preferencji wartości ostatecznych w badanych grupach

\begin{tabular}{|c|c|c|c|c|c|}
\hline Wartość ostateczna & Me_St & Me_N & $\mathbf{U}$ & p & Istotność \\
\hline Bezpieczeństwo narodowe & 15 & 14 & 128 & 0,607 & \\
\hline Bezpieczeństwo rodziny & 4 & 4 & 137,5 & 0,849 & \\
\hline Dojrzała miłość & 3,5 & 4 & 135 & 0,783 & \\
\hline Dostatnie życie & 11 & 9 & 133 & 0,732 & \\
\hline Mądrość & 7 & 4 & 84 & 0,043 & * \\
\hline Poczucie dokonania & 11 & 10 & 140 & 0,918 & \\
\hline Poczucie własnej godności & 7 & 7 & 129 & 0,631 & \\
\hline Pokój na świecie & 14,5 & 12 & 116,5 & 0,363 & \\
\hline Prawdziwa przyjaźń & 8 & 7 & 133,5 & 0,745 & \\
\hline Przyjemność & 11 & 13 & 121,5 & 0,461 & \\
\hline Równowaga wewnętrzna & 8,5 & 6 & 104 & 0,182 & \\
\hline Równość & 14 & 12 & 107 & 0,217 & \\
\hline Szczęście & 3 & 7 & 90 & 0,068 & $?$ \\
\hline Świat piękna & 15 & 16 & 139,5 & 0,904 & \\
\hline Uznanie społeczne & 10,5 & 15 & 89 & 0,064 & $?$ \\
\hline Wolność & 6 & 10 & 120 & 0,429 & \\
\hline Zbawienie & 14,5 & 13 & 115 & 0,335 & \\
\hline Życie pełne wrażeń & 11 & 15 & 94,5 & 0,096 & $?$ \\
\hline
\end{tabular}

Me_Sł - mediana w grupie osób słyszących; Me_N - mediana w grupie osób z niedosłuchem; U - test U Manna-Whitneya; $p$ - istotność asymptotyczna (dwustronna); ${ }^{*}$ - wynik istotny statystycznie na poziomie $p<0,05 ; ?$ - wynik dążący do istotności statystycznej.

rangowych w dwóch grupach niezależnych będący nieparametryczną alternatywą dla testu t dla dwóch grup). By mieć pewność, że relacja obserwowana w próbie jest wiarygodna, przyjęto poziom $\mathrm{p}=0,05$, który odpowiada $5 \%$ prawdopodobieństwu popełnienia błędu polegającego na przyjęciu rezultatu jako prawdziwego (mogącego być odniesionym do populacji), gdy w rzeczywistości tak nie jest. Istnieje wówczas jedna szansa na dwadzieścia, że odkryta różnica jest dziełem przypadku.

Wyniki przedstawione w Tabeli 6 ukazują, że różnica istotna statystycznie w badanych grupach występuje tylko dla wartości mądrość ( $U=84 ; p=0,043)$. Ta wartość ostateczna jest bardziej preferowana $\mathrm{w}$ grupie osób $\mathrm{z}$ niedosłuchem $(\mathrm{Me}=4)$ niż $\mathrm{w}$ grupie słyszących normalnie $(\mathrm{Me}=7)$. Zauważyć można jednak wśród wartości: szczęście ( $U=90$; $\mathrm{p}=0,068$; większa preferencja u osób słyszących), uznanie społeczne ( $U=89 ; p=0,064$; większa preferencja u osób słyszących) i życie pełne wrażeń ( $U=94,5 ; p=0,096$; większa preferencja u osób słyszących) zbliżenie do istotności statystycznej.

Wśród danych zawartych w Tabeli 7 nie znalazła się żadna wartość instrumentalna, która różniłaby badane grupy. Dwie pozycje zbliżyły się do poziomu istotności statycznej przyjętej w psychologii $(\mathrm{p}<0,05)$, lecz jej nie osiągnęły. Są to wartości: czysty $(\mathrm{U}=94 ; \mathrm{p}=0,093$; większa preferencja u osób z niedosłuchem) i niezależny ( $U=90,5 ; p=0,072$; większa preferencja u osób ze słuchem w normie).

\section{Analiza wyników}

Różnicę istotną statystycznie wykryto tylko w odniesieniu do jednej wartości ostatecznej - mądrość. Zauważyć można jednak pewną tendencję - wśród niektórych wartości były takie, którym do osiągnięcia poziomu istotności statystycznej brakowało kilka setnych.

Otrzymane wyniki wskazały, że osoby niedosłyszące rzeczywiście bardziej preferują prawdziwą przyjaźn niż osoby słyszące, lec nie jest to różnica istotna statystycznie. Bezpieczeństwo rodziny okazało się tak samo ważne w obu grupach, a mediana $\mathrm{z}$ rang wartości dojrzała miłość, odwrotnie do oczekiwań, była nieznacznie niższa u osób bez problemów ze słuchem. Jeżeli weźmiemy pod uwagę wartości instrumentalne, zgodnie z przewidywaniami, pozycje kochający i wybaczający są bardziej cenione przez niedosłyszących, jednak nie osiągnęły one poziomu istotności statystycznej. Wartość pomocny jest tak samo preferowana w obu grupach.

Wśród wartości ostatecznych szczęście i życie pełne wrażeń, zgodnie z przewidywaniami, były bardziej cenione przez osoby słyszące. I choć różnica okazała się nieistotna statystycznie na poziomie $\mathrm{p}<0,05$, zauważyć można tendencję do dążenia do istotności (różnica kilku setnych). Preferencja wartości dostatnie życie okazała się być odwrotna do przypuszczalnej, gdyż mniejszą medianę ma grupa osób z niedosłuchem. Mediany wartości 
Tabela 7. Różnice w preferencji wartości instrumentalnych w badanych grupach

\begin{tabular}{|c|c|c|c|c|c|}
\hline Wartość instrumentalna & Me_St & Me_N & $\mathbf{U}$ & $\mathbf{p}$ & Istotność \\
\hline Ambitny & 8 & 4 & 112,5 & 0,296 & \\
\hline Czysty & 12 & 6 & 94 & 0,093 & $?$ \\
\hline Intelektualista & 7,5 & 6 & 126 & 0,560 & \\
\hline Kochający & 8 & 5 & 131,5 & 0,693 & \\
\hline Logiczny & 8 & 10 & 135 & 0,784 & \\
\hline Niezależny & 5 & 10 & 90,5 & 0,072 & $?$ \\
\hline Obdarzony wyobraźnią & 11,5 & 15 & 101,5 & 0,154 & \\
\hline Odpowiedzialny & 3,5 & 5 & 125 & 0,535 & \\
\hline Odważny & 9,5 & 9 & 142,5 & 0,986 & \\
\hline Opanowany & 9,5 & 12 & 111,5 & 0,280 & \\
\hline O szerokich horyzontach & 10,5 & 12 & 126 & 0,560 & \\
\hline Pogodny & 12 & 13 & 115,5 & 0,346 & \\
\hline Pomocny & 8 & 8 & 123,5 & 0,501 & \\
\hline Posłuszny & 17 & 13 & 97,5 & 0,113 & \\
\hline Uczciwy & 5 & 8 & 117,5 & 0,381 & \\
\hline Uprzejmy & 10 & 13 & 103,5 & 0,175 & \\
\hline Uzdolniony & 12,5 & 11 & 136 & 0,810 & \\
\hline Wybaczający & 15,5 & 10 & 109 & 0,244 & \\
\hline
\end{tabular}

Me_Sł-mediana w grupie osób słyszących; Me_N - mediana w grupie osób z niedosłuchem; U - test U Manna-Whitneya; p-istotność asymptotyczna (dwustronna);? - wynik dążący do istotności statystycznej.

instrumentalnych wskazały zgodną z zakładaną hipotezą, choć nieistotną statystycznie preferencję pozycji obdarzony wyobraźnią, o szerokich horyzontach i pogodny u osób słyszących. Wartość odważny była zaś nieznacznie bardziej ceniona u osób z niedosłuchem.

\section{Dyskusja wyników}

Powyższe analizy wykazały, że może istnieć różnica w hierarchii wartości osób z niedosłuchem i słyszących w normie. Zebrane dane ukazały istotną statystycznie różnicę w odniesieniu tylko do jednej wartości ostatecznej - mądrości, lecz kilka innych (szczęście, uznanie społeczne, życie pełne wrażeń, niezależny - większa preferencja u osób słyszących oraz czysty - większa preferencja u osób z niedosłuchem) zbliżyło się do granicy istotności statystycznej, co daje podstawy, aby przypuszczać, że w przypadku większej grupy osób badanych, wartości te różniłyby się statystycznie w obu grupach.

Choć większość pozycji w literaturze przedmiotu zwraca uwagę na problemy społeczne osób niedosłyszących, można spotkać informacje świadczące o dążeniu do pełnej integracji ze środowiskiem słyszących. Uczniowie z wadą słuchu otrzymują pomoc od słyszących rówieśników w klasach integracyjnych. „Większość uczniów z wadą słuchu ma dobrych kolegów lub koleżanki w klasie, lecz nie ma przyjaciela" [Kobosko i wsp., 2004, s. 143]. Zarówno dzieci słyszące, jak i niedosłyszące utrzymują kontakty w szkole i poza nią. Choć nie wszyscy nauczyciele szkół integracyjnych zdają sobie z trudności $\mathrm{w}$ funkcjonowaniu ucznia $\mathrm{z}$ uszkodzeniem słuchu w grupie rówieśniczej, są gotowi ofiarować pomoc w wymagających tego sytuacjach. Być może przebadane osoby niedosłyszące wychowywały się w takich sprzyjających warunkach i pochodzą ze środowisk, gdzie nie doświadczają deprywacji zaspokojenia potrzeb związanych z drugim człowiekiem, a w efekcie cenią je tak samo, jak osoby słyszace. Ponadto w 2004 roku przeprowadzone zostały badania Kwestionariuszem Meadow-Kendall Oceny Społeczno-Emocjonalnej dla uczniów głuchych i niedosłyszących w wieku szkolnym. Wyniki pozkazały, że większość badanych z problemami ze słuchem jest przystosowana społecznie (60\%) [Kobosko i wsp. 2004].

Nie oczekiwano wystąpienia istotności statystycznej w odniesieniu do wartości mądrość. Okazała się być bardziej preferowana $\mathrm{w}$ grupie osób $\mathrm{z}$ niedosłuchem niż $\mathrm{w}$ grupie słyszących normalnie. Być może obowiązujące jeszcze niedawno odmienne traktowanie uczniów niedosłyszących powodujące wystąpienie niedoborów edukacyjnych [Krakowiak, 2003] spowodowało, że mądrość zaczęli oni oceniać wyżej niż osoby słyszące - mające dostęp do wszelkiej wiedzy (bez cięć i wyboru nauczanego materiału). Upraszczające nauczanie prowadzić mogło do wytworzenia fałszywego obrazu świata, sztywności myślowej czy negatywnego nastawienia wobec osób słyszących [Krakowiak, 2003]. Nie powoduje więc dużego zdziwienia preferowanie wartości mądrość w grupie osób niedosłyszących.

Aby otrzymać bardziej rzetelne wyniki należałoby zwiększyć badane grupy i dokonać po raz kolejny analiz 
statystycznych. Być może udałoby się wówczas wykazać więcej istotnych statystycznie różnic pomiędzy osobami ze słuchem w normie i słabosłyszących. Zastanowić należy się także, jak sprawdzać fakt zrozumienia pozycji zawartych w Skali Wartości, aby wyeliminować możliwość ich niezrozumienia. Na koniec, rozważyć można rozszerzenie badań na osoby z innych miast. Postulat ten wydaje się być zasadny, ponieważ Lublin jest ośrodkiem, gdzie osoby niedosłyszące otoczone są dobrą opieką i wsparciem.

\section{Piśmiennictwo:}

1. Birch A., Malim T.: Psychologia rozwojowa w zarysie. Od niemowlęctwa do dorosłości. Warszawa: Wydawnictwo Naukowe PWN, 2002

2. Bogdanowicz M.: Psychologia kliniczna dziecka w wieku przedszkolnym. Warszawa: Wydawnictwo Szkolne i Pedagogiczne, 1985

3. Brzozowski P.: Skala Wartości SW. Polska adaptacja Value Survey M. Rokeacha. Warszawa, 1989

4. Brzozowski P.: Wzorcowa hierarchia wartości: Polska, europejska czy uniwersalna? Psychologiczne badania empiryczne. Lublin: Wydawnictwo UMCS, 2007

5. Cieszyńska J.: Wpływ uszkodzenia słuchu na rozwój mowy. W: Wyczesany J. (red.), Dziecko z wadą słuchu w szkole podstawowej Kraków: SPONSOR, 1992; 35-41

6. Czerniawska M.: Empatia a system wartości. Przegląd psychologiczny, 2002; 45(1): 7-18

7. Czerniawska M.: Inteligencja a system wartości. Studium psychologiczne. Białystok: Trans Humana, 1995

8. Eisenberg N.: Rozwój wartości prospołecznych. W: Reykowski J., Eisenberg N., Staub E. (red.), Indywidualne i społeczne wyznaczniki wartościowania. Wrocław: Zakład Narodowy im. Ossolińskich, 1990, 99-116

9. Epstein S.: Wartości z perspektywy poznawczo - przeżyciowej teorii „ja”. W: Reykowski J., Eisenberg N., Staub E. (red.), Indywidualne i społeczne wyznaczniki wartościowania. Wrocław: Zakład Narodowy im. Ossolińskich, 1990; 11-32

10. Gałkowski T., Kaiser-Grodecka I., Smoleńska J.: Psychologia dziecka głuchego. Warszawa: Państwowe Wydawnictwo Naukowe, 1988

11. Góralówna M., Hołyńska B.: Rehabilitacja małych dzieci z wadą słuchu. Warszawa: Państwowy Zakład Wydawnictw Lekarskich, 1984

12. Grabias S.: Język, poznanie, interakcja. W: Woźniak T, Domagała A (red.), Język. Interakcja. Zaburzenia mowy. Lublin: Uniwersytet Marii Curie-Skłodowskiej, 2007; 355-77

13. Hall C., Lindzey G., Campbell J.: Teorie osobowości. Warszawa: Wydawnictwo Naukowe PWN, 2006

14. Heldstab H.: Dzieci z zaburzeniami słuchu. Biuletyn Audiofonologii, 1992; IV: 59-69

15. Herder J.: Sprachphilosophische Schriften. Hamburg: Verlag von Felix Meiner, 1960

16. Kalicka A.: Hierarchia wartości a postawy wobec osób niepełnosprawnych. Lublin: Nie publikowana praca magisterska. 2007

17. Kobosko J., Szuchnik J., Wojda P.: Kwestionariusz „JA-INNI” jako narzędzie służące do opisu tożsamości własnej młodzieży głuchej. Audiofonologia, 2004; 26: 119-33

18. Konstańczak S.: Internalizacja wartości moralnych. Słupsk: Wydawnictwo Uczelniane Pomorska Akademia Pedagogiczna w Słupsku, 2001
19. Krakowiak K.: Kim jest moje niesłyszące dziecko? Rozważania o ukrytych założeniach antropologicznych współczesnych koncepcji surdopedagogiki i audiofonologii. Lublin: Wydawnictwo Gaudium, 2003

20. Martynowicz E.: Motywy, cele, wartości. Przyczynek do zrozumienia stanu ducha i stany umysłu współczesnych Polaków. Kraków: Oficyna Wydawnicza Impuls, 2004

21. Mueller-Malesińska M., Kurkowski M.Z., Szuchnik J., Kosmalowa J.: Rozwój słuchu i mowy - fizjologia i patologia. 2002. Instytut Fizjologii i Patologii Słuchu: http: //ifps.org.pl/doc/material_dydaktyka/malesinskal.pdf

22. Pervin L.A., John O.P.: Osobowość: teoria i badania. Kraków: Wydawnictwo UJ, 2002

23. Rathus S.: Psychologia współczesna. Gdańsk: Gdańskie Wydawnictwo Psychologiczne, 2004

24. Petrozelin-Skowrońska B. (red.): Nowa Encyklopedia Powszechna PWN. Warszawa: PWN, 1997

25. Rokeach M: The nature of human values. New York: Macmillan, 1973

26. Sawczuk W.: Wartości preferowane przez studentów w okresie transformacji ustrojowej. Olsztyn: Wydawnictwo Uniwersytetu Warmińsko-Mazurskiego, 2000

27. Sękowska Z.: Wprowadzenie do pedagogiki specjalnej. Warszawa: Wydawnictwo Wyższej Szkoły Pedagogiki Specjalnej im. Marii Grzegorzewskiej, 1998

28. Staub E.: Wartości indywidualne i społeczne (grupowe) z perspektywy motywacji i ich rola w pomaganiu i krzywdzeniu innych. W: Reykowski J, Eisenberg N, Staub E, Indywidualne i społeczne wyznaczniki wartościowania. Wrocław: Zakład Narodowy im. Ossolińskich, 1999; 59-76

29. Stecewicz A., Kugler R.: Integracja szkolna dzieci z wadami słuchu. W: Woźniak W. (red.), Dziecko z zaburzeniami słuchu. Poznań: Akademia Medyczna im. Karola Marcinkowskiego w Poznaniu, 1990; 180-83

30. Stecewicz A., Szestopałko K.: Trudności w integracji w wypowiedziach absolwentek szkół wyższych, byłych podopiecznych Wojewódzkiej Poradni Rehabilitacji Dzieci i Młodzieży z Wadami Słuchu w Szczecinie. W: Woźniak W (red.), Dziecko z zaburzeniami słuchu. Poznań: Akademia Medyczna im. Karola Marcinkowskiego w Poznaniu, 1990; 184-87

31. Stocklin-Meier S.: Co naprawdę w życiu się liczy? Odkrywanie wartości z dziećmi. Białystok: Studio Astropsychologii, 2006

32. Sward M.: Dziecko głuche w środowisku słyszących rówieśników w szkole normalnej. W: Woźniak W (red.), Dziecko z zaburzeniami słuchu. Poznań: Akademia Medyczna im. Karola Marcinkowskiego w Poznaniu, 1990; 192-94

33. Wojciszke B.: System wartości osobistych a zachowanie. W: Reykowski J., Eisenberg N., Staub E. (red.), Indywidualne i społeczne wyznaczniki wartościowania. Wrocław: Zakład Narodowy im. Ossolińskich, 1990; 219-39

34. Zalewska M.M.: Funkcje słuchowe u dzieci głuchych. Warszawa: Wydawnictwa Uniwersytetu Warszawskiego, 1990 